\title{
DETERMINATION OF THE SEDIMENT PHOSPHATE COMPOSITION BY THE EDTA METHOD OF FRACTIONATION
}

\author{
L. Serrano ${ }^{1}$, M. Reina ${ }^{1}$, E. de Verd ${ }^{1}$, J. Toja' ${ }^{1} \&$ H.L. Golterman ${ }^{2}$ \\ ${ }^{1}$ Departamento de Biologia Vegetal y Ecologia, Facultad de Biologia, Universidad de Sevilla, Ap. 1095,41080 \\ Sevilla, Spain. *Association "Leiden-Camargue",Arles, France.
}

\begin{abstract}
The bioavailability of phosphate in sediments is a central issue in the study of the eutrophication of aquatic systems. The determination of the P-fractional composition is an essential tool to separate inorganic and organic P-pools in sediments. Sediments from temporary ponds of the Doiiana National Park (SW, Spain) are rich in organic matter and total P concentrations are relatively high. These ranged from 200 to $464 \mathrm{mg} \mathrm{kg}^{-1} \mathrm{dw}$. at different sites in a temporary pond in Doiiana National Park in samples taken in March and September 1999. The EDTA method (Golterman, 1996) has been shown to be a suitable P-extraction procedure for this kind of sediments. Additionally, this procedure allows the determination of the chemical structure of some organic-P substrates by enzymatic methods. With this method it appeared that the sediment phosphate composition was dominated by P-organic fractions (64-92\%). The concentration of phytic acid in the sediment ranged from 9 to $31 \mathrm{mg} \mathrm{kg}^{-1} \mathrm{dw}$. and was determined by the use ofphytase (at $\mathrm{pH} 2.5)$. The presence ofo-P in the fulvic acids extracted with 1-butanol from the $\mathbf{P}$ fraction bound to $\mathrm{CaCO}_{3}$, suggested that the org-P compounds extracted by the $\mathrm{Na}_{2}$-EDTA may be partly hydrolysed during the Murphy \& Riley reaction in these sediments.
\end{abstract}

Keywords: P-fractionation, bioavailability, phytate, temporary pond, Doiiana National Park

\section{RESUMEN}

La biodisponibilidad del fosfato en los sedimentos es el principal objetivo en el estudio de la eutrofización de los sistemas acuaticos. La determinación de la composición de las fracciones del fósforo es una herramienta esencial para separar los grupos de fósforo inorgánico y orgánico de los sedimentos. Los sedimentos de lagunas temporales del Parque Nacional de Doiiuna ( $S W$ de España) son ricos en materia orgánica y las concentruciones de P total son relativamente altas. Estas oscilan entre 200 y $464 \mathrm{mg} \mathrm{kg}^{-1}$ ps. en diferentes lugares de una laguna temporal del Parque Nucional de Doñana en muestras recogidas en Marzo y Setiembre de 1999. El me'todo EDTA (Golterman, 1996) ha mostrado ser un procedimiento adecuado para la extruccidn de fósforo para esta clase de sedimentos. De forma adicionul, este procedimiento permite la determinacidn de la estructura quimica de algunos substratos de P-orgánico por métodos enzimáticos. Con este me'todo se ha observado que la composicidn de fósforo en el sedimento estabu dominado porjracciones de P-orgánico (64-92\%). La concentración de ácido fítico en el sedimento oscilaba entre 9 y $31 \mathrm{mg} \mathrm{kg}^{-1} \mathrm{ps}$. Y fue determinudo rnediante el uso de fitasa (a pH 2.5). La presencia de P-orgánico en los ácidos fúlvicos extraídos con I-butanol de la fracción de $P$ asociada a $C a C O$, sugiere que el P-orgánico extraído con $\mathrm{Nu}$,-EDTA puede ser parcialmente hidrolizado durante la reación de Murphy \& Riley en estos sedimentos.

Palalabras clave: Fraccionamiento de P, biodisponibilidad, fitato, laguna temporal, Parque Nacional de Doñana

Limnetica 19: 199-204 (2000)

(C) Asociación Española de Limnología, Madrid. Spain 


\section{INTRODUCTION}

Despite the great importance of sediments for the bioavailability of nutrients in shallow aquatic systems, the chemistry of the sediment-water exchange is poorly understood (Golterman, 1995). The organic P-fractions have often been underestimated in sediment chemistry (Golterman \& Booman, 1988). De Groot \& Golterman (1990) and De Groot (1990) showed that a general underestimation of organic P-fractions occurred because of hydrolysis of organic P-compounds by aggressive non-specific extractants, such as $\mathrm{NaOH}$, used in the extraction of inorganic P-fractions from the sediment. In contrast, an extraction procedure of the inorganic P-fractions with chelating agents, such as EDTA, carried out at a pH near to that of the sediment avoids alterations in the sediment $\mathrm{P}$ composition (Golterman \& Booman, 1988; Golterman, 1996). Although $\mathrm{NaOH}$ is often used as an extractant for the fractionation of sedimentbound phosphate, Golterman et al. (1998) showed that cold $\mathrm{NaOH}$ does not only extract iron-bound phosphate but phytate phosphate and humic phosphate as well. Phytate (or phytic acid) is an organic phosphate that is widely spread in nature. It has been found in soils all over the world and is recognised to be the largest organic P-fraction, identified in soils (Stevenson, 1982 in De Groot \& Golterman, 1993).

The characterisation of the organic P-compounds is difficult. Specific enzymatic essays to elaborate the chemical structure of organic P-substrates are seldom used. However, several compounds such as phytic acid, nucleic acids and adenosine-phosphate have been detected in sediments by means of enzymatic activity (Feuillade \& Dorion, 1992; De Groot \& Golterman, 1993). Besides, an uncertain portion of the organic Ppool is often attributed to the presence of unspecific complexes of humic substances with iron (Paludan \& Jensen, 1995). However, the nature and bioavailability of such complexes remain to be elucidated.

The aim of this study is to present the EDTA method (Golterman, 1996) applied to the fractionation of sediments from a temporary pond in the
Doñana National Park. Additionally, some complementary analyses were performed to shed some light on the nature of the organic P-compounds in this kind of sediments. The presence of phytate is revealed by the use of an enzymatic analysis. A further extraction with 1-butanol is used to examine the presence of an organic P-fraction in the supernatant extracted by $\mathrm{Na}_{2}$-EDTA.

\section{Abbreviations used: \\ $\mathrm{o}-\mathrm{P}=$ ortho-phosphate \\ Tot $-\mathrm{P}=$ total phosphorus \\ $\mathrm{Fe}(\mathrm{OOH}) \sim \mathrm{P}=$ phosphate bound onto $\mathrm{Fe}(\mathrm{OOH})$ \\ $\mathrm{CaCO}_{3} \sim \mathrm{P}=$ calcium-bound phosphate \\ org- $\mathrm{P}_{\text {alkali }}=$ organic $\mathrm{P}$-fraction soluble in alkali \\ org- $\mathrm{P}_{\text {acid }}=$ organic $\mathrm{P}$-fraction soluble in acid $\mathrm{ROP}=$ residual organic phosphate \\ $\mathrm{Fe}(\mathrm{OOH}) \sim$ org- $\mathrm{P}_{\text {EDTA }}=$ organic $\mathrm{P}$-fraction dissolved by the Ca-EDTA/dithionite $\mathrm{CaCO}_{3} \sim$ org- $\mathrm{P}_{\mathrm{EDTA}}=$ organic P-fraction dis- solved by the $\mathrm{Na}_{2}-$ EDTA}

\section{STUDY AREA}

The Doiiana National Park is located on the Atlantic coast of Southwest Spain. The area is dominated by a Mediterranean climate with Atlantic influence, generally classified as dry subhumid. An average year includes a dry and a wet season with annual average rainfall of 580 $\mathrm{mm}$. The average wet season (from October to April) includes $80 \%$ of this, but rainfall is highly irregular from one year to another. Summers are very dry and hot, while winters are short and mild (Ménanteau, 1982).

Doiiana ponds are fed by a combination of groundwater and rainfall (Sacks et al., 1992). The ponds are very shallow temporary freshwater bodies that only receive surface drainage during floods. Their basins were formed by eolian sands stabilised in the Holocene period (Vanney \& Ménanteau, 1985). Due to its young age and lack 
of differentiation, the substrate is classified as an entisol with a different aquic moisture regime depending on flooding conditions (Siljeström \& Clemente, 1990). The percentage of sand in pond sediments ranges from $44 \%$ to $99 \%$ (Jaúregui \& Toja, 1993). Doñana sands, being of quartzitic nature, are relatively poor in calcium. Water in the ponds is rich in $\mathrm{NaCl}$ and the alkalinity is high and dominated by sodium; water $\mathrm{pH}$ usually ranges between 7 and 9. Detailed information on the limnology of these ponds is given elsewhere (López et al., 1991; Toja et al., 1991; Serrano \& Toja, 1995).

\section{MATERIAL AND METHODS}

Top sediment samples $(2 \mathrm{~cm}$ depth) were collected in March and September 1999 from three different sites in Las Verdes pond: the centre (or lowest point of the pond basin), the littoral and the floodplain. On those dates all sampling sites were dry except the centre site on March 1999 which registered a water depth of $20 \mathrm{~cm}$. Dry sediments were collected with a small garden shovel, while the wet sediment was collected with a hand gauge.

In the laboratory, dry sediments were sieved through $0.1 \mathrm{~mm}$ and wet sediments were wetsieved through a nytal mesh of $0.1 \mathrm{~mm}$ pore size. Sediment suspensions were made within $24 \mathrm{~h}$ after collection with $80-100 \mathrm{~g}$ of dry weight (dw.) in 1 litre of distilled $\mathrm{H}_{2} \mathrm{O}$. Redox potential and $\mathrm{pH}$ were measured in these sediment suspensions. The concentration of o-P was measured following the method of Murphy \& Riley (1962). The Tot-P concentration in the samples was measured after digestion with $0.5 \mathrm{M} \mathrm{H}_{2} \mathrm{SO}_{4}$ and $\mathrm{K}_{2} \mathrm{~S}_{2} \mathrm{O}_{8}$ $(1-2 \mathrm{~g})$ at $120^{\circ} \mathrm{C}$. The percentage of organic matter in the sediment was estimated in four replicates by loss on ignition $\left(450{ }^{\circ} \mathrm{C}, 5 \mathrm{~h}\right)$.

The P-fractionation of the fine sediment portions was performed in two replicates by sequential extraction with chelating compounds (Golterman, 1996). In this method the inorganic P-fraction of $\mathrm{Fe}(\mathrm{OOH}) \sim \mathrm{P}$ is first extracted with Ca-EDTA/dithionite, followed by an extraction of the inorganic P-fraction of $\mathrm{CaCO}_{3} \sim \mathrm{P}$ with $\mathrm{Na}_{2}$ EDTA, after which acid and alkaline soluble pools are extracted. The fractional composition was determined on approximately $0.6-0.7 \mathrm{~g} \mathrm{dw}$. of sediment. This procedure was slightly modified to adapt it to the Doñana sediments, rich in organic matter i.e. Tot-P from the $\mathrm{Ca}$ EDTA/dithionite and the $\mathrm{Na}_{2}$-EDTA extracts were also measured in order to quantify the pool of organic P-compounds present in these extracts (Diaz-Espejo et al., 1999).

In order to detect phytate by means of enzymatic analysis, the undigested phosphate in the sediment extracts was acidified with $1 \mathrm{M} \mathrm{H}_{2} \mathrm{SO}_{4}$. A set of aliquots $(5 \mathrm{ml})$ was incubated for $24 \mathrm{~h}$ with (and without) $0.5 \mathrm{ml}$ of phytase $\left(60 \mathrm{mg} \mathrm{l}^{-1}\right)$ from Aspergillus ficuum crude extract (Sigma). The concentration of o-P was then simultaneously measured in the aliquots, with and without enzyme, and the concentration of o-P liberated by the enzyme was then calculated by subtraction. Phytic acid from rice (Sigma) was used as a standard solution. The range of the enzyme dilution $\left(2.4-30 \mathrm{mg} \mathrm{ml}^{-1}\right)$ and the variation of the enzymatic activity with time $(0-140 \mathrm{~h})$ were investigated prior to the analyses.

A further extraction with 1-butanol (HPLC Grade) was performed on the $\mathrm{Na}_{2}$-EDTA extract by adding $10 \mathrm{ml}$ of 1-butanol and $10 \mathrm{ml}$ of $1 \mathrm{M}$ $\mathrm{H}_{2} \mathrm{SO}_{4}$ to $10 \mathrm{ml}$ of the sample. The mixture was shaken vigorously and let to separate for $20 \mathrm{~h}$. The $\mathrm{Na}_{2}$-EDTA extract was then separated into two phases: a top layer of humic acids dissolved in 1-butanol and below, the fulvic portion dissolved in the acid solution. Next, a volume of 5 $\mathrm{ml}$ of the fulvic phase was carefully taken with a pipette to measure the concentration of o-P. Another volume of $5 \mathrm{ml}$ was digested in order to measure the concentration of Tot-P.

\section{RESULTS AND DISCUSSION}

The Tot-P concentration of the fine sediment $(<0.1 \mathrm{~mm})$ of Las Verdes pond ranged from 200 to $464 \mathrm{mg} \mathrm{kg}^{-1} \mathrm{dw}$. and was lowest at the littoral site (Table 1). Similarly, the content of Tot-P in 
Table 1. Mean concentration $\pm \mathrm{SD}$ of o-P in the sediment fractions of the littoral, centre and floodplain sites during March and September 1999. Between brackets: mean concentration \pm SD of o-P liberated after the incubation with phytase. Concentraciones medius $\pm S D$ de o-P en lasfrucciones del sedimento litoral, centro y de la llanura aluvial en Marzo y Septiembre de 1999. Entre paréntesis: concentraciones medius $\pm S D$ de o-P liberado después de la incubacidn con fitasa.

\begin{tabular}{lcccccc}
\hline $\begin{array}{l}\text { P-fractions } \\
\left(\mathrm{mg} \mathrm{kg}^{-1} \mathrm{dw} \text {. }\right)\end{array}$ & March & littoral & \multicolumn{2}{c}{ centre } & \multicolumn{2}{c}{ floodplain } \\
& & Sept. & March & Sept. & March & Sept. \\
\hline $\mathrm{Fe}(\mathrm{OOH}) \sim \mathrm{P}$ & $41.0 \pm 0.5(\mathrm{ND})$ & $27.3 \pm 1.5$ & $87.8 \pm 2.7(\mathrm{ND})$ & $59.7 \pm 0.5$ & $38.5 \pm 0.7(9.2 \pm 1.1)$ & $13.4 \pm 0.3$ \\
$\mathrm{Ca}_{2} \mathrm{CO}_{2} \sim \mathrm{P}$ & $22.2 \pm 0.3(\mathrm{ND})$ & $10.7 \pm 2.3$ & $45.2 \pm 4.2(\mathrm{ND})$ & $55.5 \pm 5.5$ & $46.8 \pm 3.4(4.6 \pm 1.0)$ & $15.5 \pm 0.7$ \\
$\mathrm{Fe}(\mathrm{OOH}) \sim$ orgPEDTA & $5.3 \pm 1.0$ & $40.9 \pm 4.4$ & $18.4 \pm 2.0$ & $41.2 \pm 2.2$ & $13.1 \pm 0.9$ & $41.5 \pm 7.5$ \\
$\mathrm{Ca}_{2} \mathrm{CO}_{3}$ orgPEDTA & $1.2 \pm 0.7$ & $46.7 \pm 6.8$ & $12.4 \pm 2.5$ & $41.9 \mathrm{k} 1.3$ & 102.021 .0 & $114.7 \pm 0.7$ \\
org-Pacid & $17.7 \pm 0.0(4.0 \pm 0.4)$ & 12.021 .5 & $25.7 \pm 1.2(5.1 \pm 0.4)$ & $9.2 \pm 1.2$ & $21.6 \pm 0.8(6.3 \pm 0.8)$ & $15.5 \pm 0.6$ \\
org-Palkali & $110.22(5.1)$ & $108.7 \pm 15.6$ & $172.0 \pm 0.3(7.1 \pm 0.1)$ & $121.9 \pm 1.7$ & $225.0 \pm 17.6(11.3 \pm 0.3)$ & $154.8 \pm 5.3$ \\
ROP & $9.4 \pm 0.3$ & $10.6 \pm 0.1$ & $13.5 \pm 0.4$ & $12.3 \pm 0.4$ & $18.2 \pm 1.5$ & $8.2 \pm 0.2$ \\
$\sum$ fractions & $200.7 \pm 3.7(9.1 \pm 0.4)$ & $268.1 \pm 15.3$ & $374.9 \pm 2.5(12.2 \pm 0.3)$ & $346.3 \pm 1.1$ & $465.0 \mathrm{k} 16.9(31.4 \pm 1.3)$ & $363.3 \pm 12.2$ \\
\hline
\end{tabular}

$\mathrm{ND}=$ not detectable

the sediments of other small temporary ponds of Doñana ranged from 56 to $531 \mathrm{mg} \mathrm{kg}^{-1} \mathrm{dw}$. (Jauregui \& Toja, 1993) and from 3382 to $495 \mathrm{mg}$ $\mathrm{kg}^{-1} \mathrm{dw}$. (Diaz-Espejo et al., 1999). However, higher values were detected in the larger Dulce pond, which also showed a wider range of tot-P concentrations between the littoral and the centre sites: from 27 to $3887 \mathrm{mg} \mathrm{kg}^{-1} \mathrm{dw}$. (Jauregui \& Toja, 1993).

Given the low $\mathrm{pH}$ of the sediment samples from this pond (Table 2), calcium in the sediment cold not be in the form of $\mathrm{CaCO}_{3}$. The 'apparent P-fraction bound to $\mathrm{CaCO}_{3}$ ' (the fraction extracted by $\mathrm{Na}_{2}$-EDTA) is, in our sediments, most likely to be related to Ca-humic complexes. In particular, a fulvic subfraction of the $\mathrm{Na}_{2}$-EDTA extract was easily separated using 1-butanol. The concentration of o-P in this fulvic subfraction ranged from 7 to $26 \mathrm{mg} \mathrm{kg}^{-1} \mathrm{dw}$. and the Tot-P concentration ranged from 33 to $49 \mathrm{mg} \mathrm{kg}^{-1} \mathrm{dw}$. (Table 3). It is likely that the fulvic acids of the sediment were brought into solution during the extraction with $\mathrm{Na}_{2}$-EDTA at $\mathrm{pH} 5$ and that some organic P-compounds were partly hydrolysed during the Murphy \& Riley reaction, yielding a low concentration of o-P that was wrongly considered as an "inorganic P-fraction". However it is more likely that the previous extraction with Ca-EDTA/dithionite was not completed and part of the $\mathrm{Fe}(\mathrm{OOH}) \sim \mathrm{P}$ was still present in the sedi-
Table 2. $\mathrm{pH}$, redox potential $(\mathrm{mV})$ and concentration of $\mathrm{OM}(\%)$ in sediment samples from the littoral, centre and floodplain sites in March and September 1999. $p H$, potenciul redox ( $\mathrm{mV}$ ) y concentracidn de OM (\%) en muestras de estaciones del litoral, centro y llanura aluvial en Marzo y Septiembre de 1999.

\begin{tabular}{lrrcccc}
\hline & \multicolumn{3}{c}{ March } & \multicolumn{3}{c}{ September } \\
& $\mathrm{pH}$ & $\mathrm{mV}$ & $\% \mathrm{OM}$ & $\mathrm{pH}$ & $\mathrm{mV}$ & $\% 0 \mathrm{OM}$ \\
\hline littoral & 5.8 & $\mathbf{+ 3 4 4}$ & 9 & 6.2 & $\mathbf{+ 2 2 4}$ & 13 \\
centre & 5.6 & +94 & 15 & 6.2 & $\mathbf{+ 2 3 6}$ & 17 \\
floodplain & 5.6 & +205 & 25 & 6.4 & +230 & 22 \\
\hline
\end{tabular}

Table 3. Mean concentrations \pm SD of o-P and Tot-P $\left(\mathrm{mg} \mathrm{kg}^{-1} \mathrm{dw}\right.$. $)$ in the fulvic acids of the $\mathrm{Na}_{2}$-EDTA fractions extracted with 1-butanol in the sediment samples of the littoral, centre and floodplain sites. Concentraciones medias $\pm S D$ de P y Tot- $P$ ( $m g$ kg- $1 \mathrm{ps}$ ) en los acidos fúlvicos de lasfrucciones $\mathrm{Nu}$,-EDTA extraidus con 1-butanol en muestras de estaciones del sedimento del litoral, centro y llanura aluvial.

\begin{tabular}{lcc}
\hline & \multicolumn{2}{c}{ fulvic acids } \\
& {$[\mathrm{o}-\mathrm{P}]$} & {$[$ Tot-P] } \\
\hline littoral & $7.30 \mathrm{k} 0.3$ & $31.6 \pm 2.0$ \\
centre & $25.6 \pm 2.4$ & $48.9 \pm 0.6$ \\
floodplain & $12.0 \mathrm{k} 0.2$ & $46.1 \pm 3.4$ \\
\hline
\end{tabular}

ment and was, therefore, extracted in the following fraction by the $\mathrm{Na}_{2}$-EDTA (unpublished data). This inorganic P-fraction was then soluble in the acid phase that also included the fulvic 
acids. The Tot-P concentration was higher than the concentration of $0-P$ in these fulvic acids indicating that they contained a larger portion of organic P-compounds (Table 3).

The sediment organic P-pool at the different sites within Las Verdes pond comprised 64-92\% of the sum of the P-fractions (Table 1). In all sites, the highest phosphate concentration was found in the org- $\mathrm{P}_{\text {alkali }}$ fraction, whereas it was lowest in the org- $\mathrm{P}_{\text {acid }}$ and ROP fractions. A similar phosphate composition was found in other small temporary ponds where the organic P-pool ranged from 68 to $79 \%$ of the sum of all P-fractions (Diaz-Espejo et al., 1999).

Two results characterised the sediments from the floodplain with respect to the other sites: they were poor in $\mathrm{Fe}(\mathrm{OOH}) \sim \mathrm{P}$ but rich in organic Pfractions, especially the fraction of $\mathrm{CaCO}_{3} \sim$ org$\mathrm{P}_{\text {EDTA }}$ (Table 1). It is likely that the growth of grass (Agrostis stolonifera, Cynodon dactylon) that covered the floodplain produced a decrease of the inorganic P-fractions and an increase of the organic P-fractions due to decomposition, leaching and root activity. In contrast, the proportions of the P-fractions in the sediment of the centre and littoral sites were rather similar though the phosphate concentration of each fraction was usually higher in the sediment of the centre site.

The pond gradually dried out towards the summer. In March 1999, only the sediment of the centre site was wet, but in September 1999 the pond was completely dry. The littoral site remained dry and mostly bare during the study period while the sediment of the centre site experienced a drastic change as the pond water level dropped from $20 \mathrm{~cm}$ above the ground to $15 \mathrm{~cm}$ below it in September. Hence, the redox potential of the sediment increased from $+94 \mathrm{mV}$ in March to $+236 \mathrm{mV}$ in September in the centre site (Table 2). Besides, the floodplain sediment was likely affected by the growth of grass during spring and summer. As a result, the phosphate fractional composition of the sediment samples changed in all sites (Table 1). The concentration of phosphate in the fraction of $\mathrm{Fe}(\mathrm{OOH}) \sim \mathrm{P}$ decreased significantly in sediments from all sites (paired t-Student test, $\mathrm{P}<0.05$ ). The fraction of $\mathrm{Fe}(\mathrm{OOH}) \sim o r g-\mathrm{P}_{\mathrm{EDTA}}$ increased in all sites (Table 1) though this change was significant only in sediments of the centre and littoral sites $(\mathrm{P}<0.05)$. In September, the phosphate fractional composition of the org- $\mathrm{P}_{\text {alkali }}$ and org- $\mathrm{P}_{\text {acid }}$ fractions decreased in the sediments of all sites, but this change was significant $(\mathrm{P}<0.0 \mathrm{I})$ in the floodplain and open-water only. No significant change $(\mathrm{P}<0.05)$ was found in the ROP fraction of sediments from all sites. This fact reinforces the nonavailable nature of the ROP fraction as found in other similar studies (Díaz-Espejo et al, 1999; De Groot \& Fabre, 1993).

The changes in the sediment phosphate composition of the different sites can give some information on the bioavailability of each P-fraction. Both inorganic P-fractions of $\mathrm{Fe}(\mathrm{OOH}) \sim \mathrm{P}$ and $\mathrm{CaCO}_{3} \sim \mathrm{P}$ appeared to be a source of bioavailable $\mathrm{P}$ for phytoplankton growth (De Graaf Bierbrauwer-Wurtz \& Golterman, 1989 in Golterman, 1995). During the study period, the concentration of phosphate in the fraction of the $\mathrm{Fe}(\mathrm{OOH}) \sim \mathrm{P}$ experienced a two-fold decrease in the sediment of the floodplain site, compared to the other sites (Table 1). The 'apparent inorganic P-fraction" of $\mathrm{CaCO}_{3} \sim \mathrm{P}$ also decreased significantly only in the floodplain sediment $(\mathrm{P}<0.05)$. Therefore, it seems that these inorganic P-fractions were readily available for plant growth on the floodplain site. The o-P concentrations of other organic P-fractions also decreased significantly in some sediments (Table 1). This suggests that the organic P-pool is not a mere deposit of refractory humic phosphate, but contains some organic P-compounds, such as phytate, that may be readily available for the growth of phytoplankton and plants.

Although phytate is common in soils and sediments, it is relatively stable as it can be strongly adsorbed onto iron hydroxide and multivalent cations (De Groot \& Golterman, 1993). However, extracellular phytase activity is very common in soil microorganisms and plants (Dvoráková, 1998). The concentration of phytate in the sediment ranged from 9 to $31 \mathrm{mg} \mathrm{kg}^{-1} \mathrm{dw}$. (Table 1), but this result is surely an underestimation of the total concentration of this compound in sediments, because the enzymatic determination of this com- 
pound required a $\mathrm{pH}$ of 2.5 . At this $\mathrm{pH}$, in most extracts a precipitate occurs that prevents an unknown portion of phosphate sediment from being analysed, especially in the alkaline fractions such as the org- $\mathrm{P}_{\text {alkali }}$. Furthermore, phytase activity can be inhibited by the presence of large amounts of fulvic acids (De Groot \& Golterman, 1993). Therefore, a small volume of substrate was analysed to minimise this inhibition. Nevertheless, phytate was detected in all the undigested sediment fractions from the floodplain site, being higher in the org- $\mathrm{P}_{\text {alkali }}$ fraction (Table 1). Extractions of sediment phosphate with cold $\mathrm{NaOH}$ can easily liberate phytate and humic phosphate into the supposedly iron-bound phosphate fraction (Golterman et al., 1998). Therefore, the selection of a suitable extraction method is critical for the study of the bioavailability of $\mathrm{P}$ in the sediment, especially in organic rich sediments.

\section{REFERENCES}

DE GROOT, K.J. \& A.C. FABRE. 1993. The impact of desiccation of a freshwater marsh (Garcines Nord, Camargue, France) on the sediment-watervegetation interactions. Part 3: The fractional composition and the phosphate adsorption characteristics of the sediment. Hydrobiologia, 252: 105-116.

DE GROOT, K.J. \& H.L. GOLTERMAN. 1990. Sequential fractionation of sediment phosphate. Hydrobiologia, 192: 143-149.

DE GROOT, K.J. \& H.L. GOLTERMAN. 1993. On the presence of organic phosphate in some Camargue sediments: evidence for the importance of phytate. Hydrobiologia, 252: 105-1 16.

DIAZ-ESPEJO, A., L. SERRANO \& J. TOJA. 1999. Changes in sediment phosphate composition of seasonal ponds during filling. Hydrobiologia, 392: 21-28.

DVORAKOVA, J. 1998. Phytase: sources, preparation and exploitation. Folia Microbiol., 43: 323338.

FEUILLADE M. \& J.M. DORIOZ. 1992. Enzymatic release of phosphate in sediments of various origins. Water Research, 26: 1195-1202.

GOLTERMAN, H.L., 1995. The labyrinth of nutrient cycles and buffers in wetlands: results based on research in the Camargue (Southern France). Hydrobiologiu, 315: 39-58.

GOLTERMAN, H.L., 1996. Fractionation of sediment phosphate with chelating compounds: a simplification, and comparison with other methods. Hydrobiologia, 335: 87-95.

GOLTERMAN, H. L \& A. BOOMAN. 1988. Sequential extraction of iron-phosphate and calcium- phosphate from sediments by chelating agents. Verh.Int. Ver. Limnol., 23, 904 - 909

GOLTERMAN, H.L., J. PAING, L. SERRANO \& E. GOMEZ. 1998. Presence of and phosphate release from polyphosphates or phytate phosphate in lake sediments. Hydrobiologia, 364: 99- 104.

JAUREGUI, J. \& J. TOJA. 1993. Dinámica del fósforo en lagunas temporales del P.N. de Doiiana. Actas VI Congreso Español de Limnologia. Granada (Spain): 99-106.

LOPEZ, T., TOJA, J. \& N.A. GABELLONE. 1991. Limnological comparison of two peridunar ponds in the Doñana National Park (SW, Spain). Archivf. Hydrobiol, 120: 357-378.

MENANTEAU, L., 1982. Les Marismes $d u$ Guadalquivir, exemple de transformation d'un paysage alluvial au curs du Quaternaire recent. $\mathrm{Ph}$. D. Thesis, Université Paris-Sorbone. 252 pp

MURPHY, J. \& J.P. RILEY. 1962. A modified single solution method for the determination of soluble phosphate in natural waters. Analytical Chemicul Acta, 27: 31-36.

PALUDAN, C. \& H.S. JANSEN. 1995. Sequential extraction of phosphorus in freshwater wetland and lake sediment: significance of humic acids. Wetlands, 15: 365-373.

SACKS, L.A., J.S. HERMAN, L.F. KONIKOW \& A.L. VELA. 1992. Seasonal dynamics of groundwater-lake interactions at Doñana National National Park, Spain. J. Hydrology, 136: 123-154.

SERRANO, L \& J. TOJA. 1995. Limnological description of four temporary ponds in the Doiiana National Park (SW, Spain). Archiv f. Hydrobiol., 133: 497-516.

TOJA, J., T. LOPEZ. \& N.A. GABELLONE. 1991. Successional changes in two dune ponds (Doñana National Park). Ver. Int. Verein. Limnol., 24: 15561559.

VANNEY, J.R \& L. MÉNANTEAU. 1985. Physiographic map of the Atlantic littoral o Andalousia 1/50000. Junta de Andalucia. 